IZA DP No. 9813

Does Less Wage Compression Lead to Less Training in Germany? An Expansion of Acemoglu and Pischke's Model of Training in Imperfect Labor Markets

Renate Neubäumer

March 2016 


\title{
Does Less Wage Compression Lead to Less Training in Germany? An Expansion of Acemoglu and Pischke's Model of Training in Imperfect Labor Markets
}

\author{
Renate Neubäumer \\ University Koblenz-Landau, \\ $I A B$ and IZA
}

Discussion Paper No. 9813

March 2016

\author{
IZA \\ P.O. Box 7240 \\ 53072 Bonn \\ Germany \\ Phone: +49-228-3894-0 \\ Fax: +49-228-3894-180 \\ E-mail: iza@iza.org
}

Any opinions expressed here are those of the author(s) and not those of IZA. Research published in this series may include views on policy, but the institute itself takes no institutional policy positions. The IZA research network is committed to the IZA Guiding Principles of Research Integrity.

The Institute for the Study of Labor (IZA) in Bonn is a local and virtual international research center and a place of communication between science, politics and business. IZA is an independent nonprofit organization supported by Deutsche Post Foundation. The center is associated with the University of Bonn and offers a stimulating research environment through its international network, workshops and conferences, data service, project support, research visits and doctoral program. IZA engages in (i) original and internationally competitive research in all fields of labor economics, (ii) development of policy concepts, and (iii) dissemination of research results and concepts to the interested public.

IZA Discussion Papers often represent preliminary work and are circulated to encourage discussion. Citation of such a paper should account for its provisional character. A revised version may be available directly from the author. 


\section{ABSTRACT \\ Does Less Wage Compression Lead to Less Training in Germany? An Expansion of Acemoglu and Pischke's Model of Training in Imperfect Labor Markets*}

We expand Acemoglu and Pischke's seminal model of training in imperfect labor markets by including the system of collective wage bargaining and the components of firms' training costs. Thus we can adapt their model to institutional changes that occurred since the 1990s. The model and the empirical developments we present show that firms compensate lower returns of apprenticeship training by changing training procedures towards more training at the work place and thus by decreasing net training costs. Therefore, more decentralized wage bargaining does not result in a reduction of firms' supply of training positions.

JEL Classification: J24, J31, J52, I21

Keywords: apprenticeship training, training in imperfect labor markets, wage compression

Corresponding author:

Renate Neubäumer

Department of Economics

Institute of Social Sciences

University of Koblenz-Landau

August-Croissant-Straße 5

76829 Landau

Germany

E-mail: neub@uni-landau.de

\footnotetext{
${ }^{*}$ I am grateful to Jörn-Steffen Pischke for an intensive and very fruitful discussion on the expansion of his model of training in imperfect labor markets and the German system of apprenticeship training. Furthermore, I thank David Card, Michael Reich and the participants of the Labor Seminar and the IRLE Lunch at UC Berkley for helpful comments and inspiring discussions.
} 
Does Less Wage Compression Lead to Less Training in Germany? - An Expansion of Acemoglu and Pischke's Model of Training in Imperfect Labor Markets

\section{Renate Neubäumer}

\section{Introduction}

The German dual system of vocational education and training was successful in the past. It created high skill levels for non-college bound youths and led to relatively low youth unemployment, because it facilitated an orderly school-to-work transition (Freeman and Schettkat, 2001; Neubäumer, 1999; Ryan, 2001).

Before this background, Acemoglu and Pischke $(1998,1999)$ developed a model of training in imperfect labor markets. It was able to explain why, in the 1990s, the United States had a high wage-high mobility-low training equilibrium and, in contrast, Germany had a low wage-low mobility-high training equilibrium: The German institutional framework of labor markets, particularly the industry-wide system of collective bargaining, resulted in high wage compression. Therefore, German firms gained high returns from apprenticeship training and accepted high training costs.

Since then, however, the system of collective wage bargaining has changed. As a result, wage compression and the returns of apprenticeship training decreased. On the other hand, firms' investments in apprenticeship training slumped from about $€ 10.7$ billion in 2000 to about $€ 6.4$ billion in 2007. Do these developments mean that the successful German training system is at risk?

In order to answer this question, we contribute to the literature by continuing and enhancing Acemoglu and Pischke's model. First, we include collective bargaining, which increases the wages of unskilled workers more than those of skilled workers and thus leads to higher wage compression. Because of this, our model can explain how changes in the system of collective bargaining influence the returns of apprenticeship training and thus firms' ability and willingness to bear high training costs. Second, we model how the different components of training costs influence the parameters of the training equilibrium. In this way, our model enables us to draw conclusions about the impact that changes of the different cost components have on the training equilibrium.

In addition, we present empirical evidence demonstrating the usefulness and necessity of an expansion of Acemoglu and Pischke's model of training in imperfect labor markets. First, we show in what way the system of collective wage bargaining has changed and give a short overview on the development of wage inequality. Second, we show how the different components of firms' (net) training costs have changed. In addition, we present empirical evidence demonstrating the usefulness and necessity of an expansion of Acemoglu and Pischke's 
model of training in imperfect labor markets. First, we show in what way the system of collective wage bargaining has changed and give a short overview on the development of wage inequality. Second, we show how the different components of firms' (net) training costs have changed.

Third, we present evidence as to how the supply and demand for apprenticeships have developed and especially how the number of training positions and thus the training equilibrium have changed.

Finally, we conclude and give an outlook to further research.

\section{Theoretical background}

\subsection{Acemoglu and Pischke's model and its background}

Acemoglu and Pischke's model of training in imperfect labor markets builds on Becker's human capital approach that has shaped and still shapes thinking on training. Becker (1964) concluded that there is no firm-sponsored general training in perfect labor markets.

However, Swiss and especially German firms incur significant costs when investing in vocational training, though this training often entails important transferable skills. Therefore, German and Swiss researchers have developed several investment-oriented models of vocational training, starting as early as the 1980s (e.g., Franz, 1982; Neubäumer, 1993, 1999). Furthermore, other models explain why firms pay for (general) further training (e.g., Katz and Ziderman, 1990; Franz and Soskice, 1995; Leuven, 2005).

In conclusion, Acemoglu and Pischke $(1998,1999)$ merged most of these investment-oriented models into a single approach and coined the term wage compression which refers to the fact that a firm's rent from skilled workers is higher than from unskilled workers. We use their analytic model (Acemoglu and Pischke, 1999, pp. F133) as a basis for our research.

A firm only trains if the costs of training in period $0, \mathrm{C}$, are not higher than its returns from training in period $1 .{ }^{1}$ These returns depend on the wage of skilled workers, $\mathrm{w}$, their productivity, $\alpha$, and the probability that a skilled worker stays in the training firm, $\mathrm{P}$.

$$
\mathrm{C} \leq \mathrm{P} \cdot(\alpha-\mathrm{w})
$$

Therefore, firm-sponsored general training only takes place in imperfect labor markets, in which the productivity of a skilled worker is higher than his wage, and firms gain rents from training. The productivity of a skilled worker depends on his ability, $\eta$, which only takes two values: $\eta=0$ with probability $p$, and $\eta=1$ with probability $(1-p)$. A worker with a lower ability

\footnotetext{
1 Acemoglu and Pischke further assume that there is no discounting, that all parties are risk-neutral, and that training, $\tau$, takes only two values $\tau \in\{0,1\}$.
} 
has a lower productivity $\alpha(\eta=0)=1$, whereas a high-ability worker's productivity amounts to $\alpha(\eta=1)=\alpha>1$.

Training firms and non-training firms have asymmetric information. An internal employer discovers the ability of a worker at the end of period 0 , whereas an external employer does not get this information.

Training firms only retain high-ability workers, whereas the other skilled workers are laid off. Training firms pay their skilled workers a wage, $\mathrm{w}<\alpha(\eta=1)$, and thereby realize a rent, $r_{a i}=(\alpha(\eta=1)-w)$. However, workers, who get an offer from their internal employer, quit (with probability q) if they get a higher wage offer from an external employer. Thus only $(1-p) \cdot(1-q)$ skilled workers stay with their training firm.

External employers usually offer skilled workers an outside wage $\mathrm{v}_{0}<\mathrm{w}$. The reason behind this is that they do not know the workers' ability that is they do not know whether the workers have quit voluntarily or have been laid off. As there is perfect competition in external labor markets, external firms do not gain a rent by employing skilled workers. They are wage-takers of $\mathrm{v}_{0}$, which equals the expected value of a skilled worker's productivity:

$$
\mathrm{v}_{0}=\mathrm{E}(\alpha(\eta=0,1))=\frac{\mathrm{p} \cdot \alpha(\eta=0)+(1-\mathrm{p}) \cdot \mathrm{q} \cdot \alpha(\eta=1)}{\mathrm{p}+(1-\mathrm{p}) \cdot \mathrm{q}}=\frac{\mathrm{p} \cdot 1+(1-\mathrm{p}) \cdot \mathrm{q} \cdot \alpha}{\mathrm{p}+(1-\mathrm{p}) \cdot \mathrm{q}}
$$

Young workers learn about their comparative advantage in period 1 . This is captured by a matchspecific shock, $\theta$, meaning that a young worker's productivity increases for a number of external employers for which they are better suited. The distribution of $\theta$ is uniform over $[0,1]$, and $\theta$ is publicly observed. As a result, an external employer offers a skilled worker with a higher productivity a wage, $\mathrm{v}$,

$$
\mathrm{v}=\mathrm{v}_{0}+\theta
$$

A high-ability worker does not quit his training firm if $\mathrm{w}>\mathrm{v}=\left(\mathrm{v}_{0}+\theta\right)$, i.e. if $\left(\mathrm{w}-\mathrm{v}_{0}\right)>\theta$. Therefore, the probability for quitting the training firm, $q$, is given by

$$
\mathrm{q}=1-\left(\mathrm{w}-\mathrm{v}_{0}\right) \quad \text { with }\left(\mathrm{w}-\mathrm{v}_{0}\right) \in[0,1]
$$

For $\left(\mathrm{w}-\mathrm{v}_{0}\right)=1, \mathrm{q}=0$ applies, that is no skilled worker quits his training firm, as he would not get a higher wage in an outside firm.

For $\left(\mathrm{w}-\mathrm{v}_{0}\right)=0, \mathrm{q}=1$ applies, that is all (general) skilled workers quit their training firms. (This is Becker's case, where asymmetric information does not prevent perfect competition.) 
Thus the profit (or loss) of a training firm, $\pi$, amounts to

$$
\pi=(1-p)\left(w-v_{0}\right)(\alpha-w)-C
$$

$\left((1-p)\right.$ is the share of high-ability workers, $\left(w-v_{0}\right)$ is the probability that these workers do not quit, $(\alpha-w)$ is their future rent, and $C$ are the training costs.)

The optimal, profit-maximizing wage offer of a training firm, $\mathrm{w}_{\mathrm{opt}}$, equals

$$
\mathrm{w}_{\mathrm{opt}}=\frac{\alpha}{2}+\frac{\mathrm{v}_{0}}{2}
$$

We enter equation (6) and $\mathrm{q}=\left(1-\mathrm{w}+\mathrm{v}_{0}\right)$ in equation (2):

$$
\mathrm{v}_{0}=\frac{\mathrm{p}+(1-\mathrm{p})\left(1-\frac{\alpha}{2}+\frac{\mathrm{v}_{0}}{2}\right) \cdot \alpha}{\mathrm{p}+(1-\mathrm{p})\left(1-\frac{\alpha}{2}+\frac{\mathrm{v}_{0}}{2}\right)}
$$

As a result, the common component of the outside wage, $v_{0}$, is only determined by the share of high-ability workers, (1-p), and the productivity of skilled workers with high ability, $\alpha . v_{0}$ is an endogenous variable; external firms cannot decide about their wage for skilled workers.

The same applies for training firms. Their wages for skilled workers are a function of $\mathrm{v}_{0}$ and thus depend on (1-p) and $\alpha$, only:

$$
\mathrm{w}=\frac{\mathrm{p}+(1-\mathrm{p})(1-\alpha+\mathrm{w}) \cdot \alpha}{2 \mathrm{p}+2(1-\mathrm{p})(1-\alpha+\mathrm{w})}+\frac{\alpha}{2}
$$

Nevertheless, training firms gain a rent from their skilled workers due to asymmetric information, $\mathrm{r}_{\mathrm{ai}}$; therefore, they sponsor general training. This is the main result of Acemoglu and Pischke's model. Furthermore, they emphasize the importance of the institutional framework for the German apprenticeship system to work: Radical changes in labor market institutions may have unforeseen, counterproductive consequences (for the German training system) (Acemoglu and Pischke, 1999, p. F136).

\subsection{An enhanced model for apprentice' training in Germany}

The system of collective bargaining is a central institution of the German labor market that has changed enormously since the 1990s, when Acemoglu and Pischke developed their model. Therefore, we describe this system and incorporate its impacts on wage compression and thus on wages of skilled workers into their model. 


\subsubsection{Incorporating the system of collective wage bargaining}

One pillar of the German system of collective bargaining is the constitutionally protected principle of bargaining autonomy. It gives trade unions and employers' associations the right to regulate wages and working conditions without state interference. (In addition, firms have the right not to conclude collective agreements and to make an individual contract with their employees instead.) Collective agreements are legally binding, provided that a firm is a member of the industry-specific employers' association, and the employee is a member of the industryspecific trade union. However, member firms generally apply collective contracts to their nonmember labor force as well (otherwise, these workers would feel compelled to join a trade union).

These collectively agreed wages are minimum terms. Firms bound by collective agreements cannot undercut but only improve upon these wages (principle of benignity). Exceptions are only possible if there is an opening clause in the central contract that allows firm-level negotiations, for example in case a firm incurs a high loss (e.g., Garloff and Guertzgen, 2012).

In contrast to firm-level collective bargaining in the United States, wages in Germany are mainly negotiated in a more centralized fashion at industry level between a single union and an employers' association, leading to industry-wide collective agreements for specific regions (or for the whole of Germany). Many German employers prefer multi-company bargaining, because it helps to keep the workplace separate from trade union activities. Thus distribution conflicts remain outside the firm, which contributes to cooperative labor relations. Separate agreements between specific companies and trade unions are rare. As a whole, the German system of wage bargaining is characterized as medium centralized.

In the literature, there is no doubt that the degree of centralization of a country's collective bargaining system influences wage levels and particularly wage inequality (Calmfors and Driffill, 1988; Calmfors, 1993; Schettkat, 2003). Perfectly decentralized wage bargaining systems (like in the United States) lead to high wage differentials, whereas coordinated collective bargaining (like in Germany) dampens wage inequality, especially by reducing wage differentials between lowpaid and higher-paid workers (Rowthorn, 1992; Freeman and Schettkat, 2001). For example, German trade unions often negotiate a basic amount for all workers and/or higher percentage wage increases for lower wage groups.

Against this institutional background, we assume that German firms have some monopsony power and obtain rents by employing skilled and unskilled workers. Collective bargaining on the industry level reduces these rents and hence leads to higher wages. The benefit of this is greater for unskilled workers, whose wages increase more than those of skilled workers. As a result, wage compression is higher in the case of collective bargaining. German training firms, therefore, gain an additional rent $r_{\mathrm{wc}}$ from skilled workers who earn lower wages (in relation to unskilled workers): 


$$
\mathrm{w}_{\mathrm{cb}}=\mathrm{w}-\mathrm{r}_{\mathrm{wc}} \text { and } \mathrm{v}_{0 \mathrm{cb}}=\mathrm{v}_{0}-2 \mathrm{r}_{\mathrm{wc}}
$$

Furthermore, wage compression reduces the wage of skilled workers on the external labor market, $\mathrm{v}_{0 \mathrm{cb}}$, more than the wage in the training firm, $\mathrm{w}_{\mathrm{cb}}$, and hence leads to a higher retention rate of graduates:

$$
\mathrm{w}_{\mathrm{cb}}-\mathrm{v}_{0 \mathrm{cb}}=\mathrm{w}-\mathrm{v}_{0}+\mathrm{r}_{\mathrm{wc}}
$$

Both effects lead to higher profits from training, $\pi$, which increase with a rising rent:

$$
\begin{aligned}
& \pi=(1-p)\left(w-v_{0}+r_{w c}\right)\left(\alpha-w+r_{w c}\right)-C \\
& \frac{d \pi}{d_{w}}=(1-p) \cdot\left(w-v_{0}+r_{w c}\right)+(1-p) \cdot\left(\alpha-w+r_{w c}\right)
\end{aligned}
$$

\subsubsection{Implications of a lower wage compression for training costs}

Conversely, a change in collective bargaining that reduces wage compression and thus the additional rent from skilled workers, leads to lower profits due to higher wages of skilled workers and lower retention rates. (In practice, the crucial factor is a relatively higher wage of skilled workers - as a result of a wage raise for skilled workers or a wage reduction for unskilled workers.)

Graph 1 demonstrates that lower rents from skilled workers, $r_{w c}$, force some firms to stop training. In the case of training costs of 0.2 and a productivity of 3 (dotted line) and a $r_{\mathrm{wc}}$ of $1, \pi$ amounts to 0.32 . If $r_{\mathrm{wc}}$ falls to $0.6, \pi$ decreases to 0.10 , and if $r_{\mathrm{wc}}$ falls to $0.2, \pi$ becomes -0.06 , that is the firm makes a training loss.

\section{Graph 1: Profits from Training as a Function of the Rent through Wage Compression due to Collective Bargaining (Simulation)}

Consequently, our model implies that more decentralized collective bargaining and (relatively) higher wages for skilled workers make apprenticeship training less profitable for firms. Therefore, the low wages-low mobility-high training equilibrium in Germany might be at risk.

However, firms can reduce their training costs. For this reason, we additionally analyze how changes of the different cost components affect the training equilibrium.

\subsubsection{Modelling training costs in the German apprenticeship system}

To achieve this, we first have to describe the training system and its institutional background. An apprenticeship usually lasts three years and combines an occupation-specific theoretical education in vocational schools with practical on-the-job training in firms, supervised by senior 
colleagues or full time trainers. Its basis is a training contract that obliges the apprentice to work for the firm and to attend vocational school, and obliges the firm to train the apprentice according to the occupation-specific curriculum and to pay him/her an apprentice's wage. Additionally, many firms impart theoretical competence and practical skills through internal courses or in their own training centers in order to improve the productivity of their future workers. Apprentices have to pass an external final exam $^{2}$ and graduate with a certificate recognized throughout Germany, attesting that the apprentice has obtained a vocational qualification.

For young people, even those with good grades, an apprenticeship is an attractive alternative to a tertiary education: They earn an apprentice's wage during training, and they finish their occupational qualification at a younger age. ${ }^{3}$ Furthermore, many apprenticeships provide entry to attractive occupations, such as industrial mechanic, medical assistant or skilled bank clerk. As a consequence, about 60 percent of all young people in Germany chose an apprenticeship in the past.

Second, we take a closer look at training costs. ${ }^{4}$ Firms' net costs of training, C, result from apprentices' wages, $\mathrm{w}_{\mathrm{a}}$, firms' direct training costs, $\mathrm{c}_{\mathrm{d}}$, and the productivity of apprentices, $\alpha_{\mathrm{a}}$ :

$$
\mathrm{C}=\left(\mathrm{w}_{\mathrm{a}}+\mathrm{c}_{\mathrm{d}}\right)-\alpha_{\mathrm{a}}
$$

Therefore, firms can reduce $\mathrm{C}$ by paying their apprentices lower wages, by reducing $\mathrm{c}_{\mathrm{d}}$, i.e. the costs for training personnel and the expenditures for material and equipment, and by increasing apprentices' productivity during training. However, this will affect the firms' future returns of training, which depend on the probability that the graduated apprentices remain in the training firms and on their future productivity, $\alpha$.

$\mathbf{w}_{\mathbf{a}}$ is an incentive to join the apprenticeship system, particularly for high-ability adolescents, who could enter tertiary education instead. Accordingly, we can expect that a lower $\mathrm{w}_{\mathrm{a}}$ will result in a lower share of apprentices with high ability, (1-p):

2 The final exam of an apprenticeship, which is conducted at the local chamber of commerce, consists of a written exam and a practical test. The examination contents are set by a central, often nationwide examination board of the chambers of commerce.

3 Young people with a higher education entrance qualification complete an apprenticeship at the age of 21, whereas they graduate from university between the ages of 24 and 27 with an MA, which most German firms demand.

${ }^{4}$ Our modeling of training costs follows the cost-benefit model by the Expert Commission on Costs and Financing of Vocational Education and Training (Sachverständigenkommission, 1974). It was the basis of several CostBenefit Surveys of the Federal Institute of Vocational Education and Training (BIBB) (see for example Beicht et al., 2004; Schönfeld et al., 2010). 


$$
1-\mathrm{p}=1-\mathrm{p}\left(\mathrm{w}_{\mathrm{a}}\right) \quad \text { with } 1-\frac{\mathrm{dp}}{\mathrm{dw}_{\mathrm{a}}}>1
$$

$\mathbf{c}_{\mathbf{d}}$, the costs for training personnel and infrastructure, are especially high if firms offer internal courses and/or have their own training centers where apprentices are trained off the job to gain additional skills. Accordingly, firms can reduce $c_{d}$ by decreasing the hours of instruction and linked to this - by reducing internal courses and cutting back or closing down their training centers. However, in most cases these measures will reduce training quality and hence result in a lower future productivity of graduates, $\alpha$.

$\boldsymbol{\alpha}_{\mathbf{a}}$, the productivity of the apprentice, depends on the organization of their training. If apprentices spend more time being trained on the job and less time with off-the-job training (in training centers, internal or external courses or other forms of tuition), $\alpha_{a}$ increases. In the literature, it is discussed controversially whether more training at the workplace (and hence a higher $\alpha_{\mathrm{a}}$ ) decreases the prospective productivity of skilled workers, $\alpha$. On the one hand, this might lead to a less general and broad vocational education, a factor that is central for the German apprenticeship training and the productivity of its graduates (Bahl et al., 2004; Severing 2003). On the other hand, this might result in a higher vocational identity and more special competencies and might even increase the graduates' productivity (Bremer and Hassler, 2004; Grollmann and Rauner, 2007). However, if on-the-job training is cheaper and does not reduce future productivity, firms would train apprentices exclusively at the workplace.

Before this background, we assume:

$$
\alpha=\alpha\left(\mathrm{c}_{\mathrm{d}}, \alpha_{\mathrm{a}}\right) \text { with } \frac{\partial \alpha}{\partial \mathrm{c}_{\mathrm{d}}}>1 \text { and } \frac{\partial \alpha}{\partial \alpha_{\mathrm{a}}}<1
$$

Finally, we incorporate the different components of training costs and its effects on the returns of apprenticeship training in the equation for firms' training profits:

$$
\pi=\left(1-\mathrm{p}\left(\mathrm{w}_{\mathrm{a}}\right)\right) \cdot\left(\mathrm{w}-\mathrm{v}_{0}+\mathrm{r}_{\mathrm{wc}}\right) \cdot\left(\alpha\left(\mathrm{c}_{\mathrm{d}}, \alpha_{\mathrm{a}}\right)-\mathrm{w}+\mathrm{r}_{\mathrm{wc}}\right)-\left(\mathrm{c}_{\mathrm{d}}+\mathrm{w}_{\mathrm{a}}-\alpha_{\mathrm{a}}\right)
$$

A firm can improve its training profit by decreasing its training costs only if the changes of the different cost components are not overcompensated by its negative effects on training returns:

$$
\frac{\partial \pi}{\partial \mathrm{w}_{\mathrm{a}}}=-\frac{\mathrm{dp}}{\mathrm{dw}_{\mathrm{a}}} \cdot\left(\mathrm{w}-\mathrm{v}_{0}+\mathrm{r}_{\mathrm{wc}}\right) \cdot\left(\alpha-\mathrm{w}+\mathrm{r}_{\mathrm{wc}}\right)-1
$$

Lower wages lead to much lower returns if thus many high-ability workers do not enter the apprenticeship system but choose a tertiary education instead. These high-ability workers would otherwise have obtained a high future productivity (compared to their wages). 


$$
\frac{\partial \pi}{\partial c_{d}}=(1-p) \cdot\left(w-v_{0}+r_{w c}\right) \cdot \frac{d \alpha}{d_{d}}-1
$$

Lower direct training costs - due to less instruction - particularly affect future returns if they considerably decrease the productivity of skilled workers, and if most apprentices stay in the firm after graduation.

$$
\frac{\partial \pi}{\partial \alpha_{a}}=(1-p) \cdot\left(w-v_{0}+r_{w c}\right) \cdot \frac{d \alpha}{d \alpha_{a}}+1
$$

More training on the job only reduces firms' training profits if it has a high negative effect on the future productivity of the skilled workers and if most apprentices stay in the training firm.

\section{Empirical evidence}

As a last point, we provide empirical evidence that an expansion of Acemoglu and Pischke's model is necessary and useful to explain the development of the German apprenticeship system since the 1990s. First, we analyze how the system of collective wage bargaining has changed and how this has affected wage inequality and wage compression. Second, we take a closer look to find out which components of training costs have changed that may have influenced the training equilibrium. Third, we investigate whether there is already empirical evidence that the German training apprenticeship system is at risk.

\subsection{Decentralization of collective bargaining and wage inequality}

In the last two decades, Germany has seen a strong trend towards decentralization of wage bargaining. One major cause for this was a persistent process of disorganization: The membership in unions and employers' associations decreased (Schnabel and Wagner, 2006; Silvia and Schroeder, 2007) and led to a much lower percentage of employees being covered by collective agreements. Between 1996 and 2006, the coverage rate decreased from 69\% to 57\% in West Germany and from 56\% to $41 \%$ in East Germany (Ellguth and Kohaut, 2007). This development is often called an external erosion of German collective agreements (Oechel, 2005). Furthermore, an internal erosion of German collective agreements took place: Nowadays, central contracts much more frequently include opening clauses that delegate bargaining competencies to the plant-level. As a result, employees' representatives often negotiate pacts for employment with their firms. They accept wages that are lower than the collectively agreed wages in return for job guarantees or the safeguarding of a production location (Bispinck and Schulten, 2003; Oechel, 2005; Seifert and Massa-Wirth, 2005; Brändle, Heinbach, and Meier, 2011).

This decentralization goes along with higher wage inequality, as a number of studies prove (Gernandt and Pfeiffer, 2006; Kohn, 2006; Dustmann et al., 2009; Card et al., 2012; Dustman et al., 2014). Though these studies are based on different data sets and use different subpopulations, 
time periods, and measures of wage inequality, they all reach the same conclusion: In Germany, wage dispersion has increased considerably since the beginning of the 1990s or the mid-1990s, respectively.

\section{Table 1: Wage Dispersion, 1992 and 2001 in Germany}

Table 1 presents the results of Kohn (2006). He measures wage dispersion by percentile differences for men and women in West and East Germany. From 1992 to 2001, wage inequality increased for all groups, as can be seen in the rise of the 80-20-percentile difference between 7 and 30 percentage points. For women, the wage dispersion rose especially at the bottom of the wage distribution, whereas for men it rose at the top.

Dustmann et al. (2009) come to similar results for the period from 1990 to 2004 (see the indexed wage growth of the 15 th, 50th and 85 th percentiles in their figure II, p. 851). In addition, they analyze the effect of declining unionization rates by using the decomposition method proposed by DiNardo et al. (1996). Their results indicate that the decline in union recognition in the 1990s had a profound impact on the wage structure, especially at the lower end of the distribution (Dustman et al., 2009, p. 862).

Card et al. (2012) observe an enormous rise of wage inequality between 1996 and 2009. In this period, the gap between the 20th and 80th percentile of wages expanded by approximately $20 \log$ points. Simultaneously, the share of employees outside sectoral agreements rose sharply. Using models with additive fixed effects for workers and establishments, the authors find that the increased wage inequality results mainly from three factors: rising heterogeneity between workers, rising premiums at different establishments, and rising assortativeness between workers and establishments. Concerning the impact of collective bargaining, they conclude: Regulatory reforms and other changes may have made it easier for German employers to deviate from sectoral wage contracts that artificially raised wages - particularly for lower skilled workers and compressed the wage structure (Card et al., 2012, p. 37).

Finally, Gerlach and Stefan (2006) did research on the effects of bargaining regimes on wage dispersion, with the result that wage inequality is significantly lower in firms with multiemployer agreements, bargained by trade unions and employers' associations, than in firms with individual contracts.

All these results show that more decentralized wage bargaining led to less wage compression and thus to (relatively) lower rents from skilled workers, $r_{w c}$. Therefore, a continuation of Acemoglu and Pischke's model is necessary to analyze how that affects the training equilibrium. Our equations 9 to 12 show that there are two reasons why falling rents from skilled workers $\left(\mathrm{dr}_{\mathrm{wc}}<\right.$ 0 ) lead to lower training profits, $\pi$ : The wages of skilled workers increase and the retention rate of graduated apprentices, $\mathrm{w}_{\mathrm{cb}}-\mathrm{v}_{0 \mathrm{cb}}$, decreases (as a lower rent reduces the wage in the training firm, $\mathrm{w}_{\mathrm{cb}}$, more than the wage of skilled workers on the external labor market, $\mathrm{v}_{0 \mathrm{cb}}$ ). Consequently, 
lower rents from skilled workers force some firms to stop training or to reduce their training costs.

\subsection{Change of training costs and their components}

Therefore, it is not surprising that firms' net costs of training (per apprentice and year) slumped from $€ 6,000$ in 2000 to $€ 3,600$ in 2007 (table 2). However, this suggests the question as to which components of firms' net training costs changed and what effects this can be expected to have on the training equilibrium.

\section{Table 2: German Firms' Costs and Benefits of Training, 2000 and 2007}

Apprentice wages, $\mathrm{w}_{\mathrm{a}}$, did not contribute to lower training costs. They increased even more than union wage rates (14 percent compared to 12 percent). The institutional background to this is that in most medium-size and large firms, apprentice wages, $\mathrm{w}_{\mathrm{a}}$, are fixed in collective agreements (together with union wages); only smaller and some medium-size firms fix $\mathrm{w}_{\mathrm{a}}$ in individual contracts. Furthermore, most adolescents with a higher education entrance qualification choose apprentice positions in larger firms or competitive medium-size firms, where apprentice wages rose even more. Thus there was only a small additional incentive for high-ability adolescents to choose an apprenticeship instead of a higher education, which might have led to a slightly higher share of high-ability apprentices, (1-p), and thus to higher returns from training. Together, the effects of higher costs and slightly higher returns from training could not compensate the lower returns due to decreasing rents from collective bargaining.

Firms' costs for training personnel and infrastructure, $\mathrm{c}_{\mathrm{d}}$, led to a moderate increase in training costs. They went up by only 2.7 percent - far less than wages and prices in the same period. Therefore, the quality of apprenticeship training may have declined slightly and may have caused a small drop in future productivity of skilled workers. Thus the development of $\mathrm{c}_{\mathrm{d}}$, too, could not prevent firms from training less in response to decreasing rents from skilled workers.

What was crucial for the slump of firms' net costs of training was a rise in apprentices' productivity, $\alpha_{\mathrm{a}}$, by 48 percent (Schönfeld et al., 2010). The reason for this is that many firms fundamentally changed their training process: They train and educate their apprentices much less on internal courses, in firms' training centers or by other forms of tuition, and considerably more at the workplace. As a result, apprentices perform fewer unproductive activities and a lot more productive ones: Between 2000 and 2007, the share of apprentices' working time spent doing unproductive tasks decreased from 43 to 22 percent, whereas the amount of time spent doing skilled and unskilled productive tasks rose from 25 to 43 percent and from 29 to 35 percent, respectively (Beicht et al., 2004; Schönfeld et al., 2010).

However, this rise in apprentices' productivity, $\alpha_{a}$, could only compensate firms for a lower wage compression if it did not lead to a decrease (or only a slight decrease) in the prospective 
productivity of skilled workers, $\alpha$; even a doubling of $\alpha_{a}$ can only have had a marginally negative effect on $\alpha$.

Otherwise, lower wage compression would have led to a lower training equilibrium and less training positions.

\subsection{Effects on apprentice positions}

Such a decrease of apprentice positions would have caused problems in Germany in the 2000s, as the baby boomer generation reached an age when many of them left school and applied for apprenticeships (or other vocational education positions). Due to this, the demand for apprentice positions had increased by $2 \%$ between the years 2000 and 2007 (table 3 ).

\section{Table 3: Development of Apprenticeship Positions, 2000 and 2007 in Germany}

On the other hand, firms did not reduce their supply of training positions, so that the number of apprentices remained unchanged 1.78 million, and still more than 60 percent of an age cohort were able to and did do an apprenticeship.

\subsection{Decline of training quality?}

This unchanged number of apprentices suggests that the German system of vocational education and training is not at risk. However, this may only be the case in terms of quantity. ${ }^{5}$ For example, Severing warns that a substantial increase in training at the workplace might change vocational education and training to a process of continual breaking in at the workplace (Severing, 2003, p. 4). If it is indeed the case that a doubling of apprentices' productivity does not have a negative impact on training quality and future productivity of skilled workers, we need to wonder why firms did not train far more at the workplace in the past.

To answer this question, we point to two developments that may have improved the conditions for on-the-job apprenticeship training.

Changes of firms' production processes and skill requirements. The change of work organization and production processes since the end of the 1990s was mainly characterized by a higher degree of specialization due to an increased demand for flexibility and a higher complexity of production processes. As a result, many medium-skilled workers have fewer tasks, and their tasks are more narrowly defined than in the past. These workers do skilled routine jobs (Autor et al., 2003) and thus need fewer skills. On the other hand, the restructured production processes call for more social and communicative competencies in order to work in teams and - in service occupations -

\footnotetext{
5 Jörn-Steffen Pischke, who provided interesting comments on a previous version of this paper, also raised the question of whether the German system of apprenticeship training might be at risk in terms of quality due to increased on-the-job training.
} 
deal with customers (Baethge et al., 2006; Lacher, 2006). (The empirical evidence for the restructuring of production processes and changed skill requirements consists of a large number of case studies of German firms, both in the manufacturing sector (electrical industry, automotive manufacture, machine and plant construction) and in the service sector (banks, insurance companies, IT- and multimedia companies) (Springer, 1999; Jürgens, 2006; Baethge et al., 2006).

These developments may have promoted more training at the workplace for several reasons: Skilled routine work requires fewer broad, general skills, which are often imparted in courses and training centers, and more social and communicative competencies, which can be improved at the workplace. Moreover, some routine jobs only demand few, narrowly defined skills and can thus be done by apprentices after relatively short instruction.

Changes in the regulatory framework. In the tripartite German training system, representatives of employers, workers and the public ${ }^{6}$ cooperate closely in order to adapt the regulatory framework of the vocational training system to technological and organizational change and other developments.

For the changes in this framework, the turn toward the new concept of process-orientated training was crucial (Sauter, 1999; Koch and Meerten, 2003; Bahl et al., 2004). This concept is based on the idea that firms can impart skills and competencies relevant to the occupation-specific curriculum via concrete, hands-on tasks. These tasks are derived from the actual work and business processes of the training firm, and apprentices prepare the task, carry it out and reflect upon it afterwards. In this way, the technologies, products and services of the training firm become the standards for training, potentially at the expense of the breadth and comprehensiveness of the training.

Furthermore, firm-based exams were introduced, which not only made the training system more flexible and differentiated (Busemeyer, 2009; Busemeyer et al., 2012), but also allows for more firm-specific approaches and more training on the job.

All in all, the changes in work organization and production processes and the regulatory framework of apprenticeship training have improved the conditions for more training at the workplace. However, further research is necessary to determine how these developments have influenced training costs and training quality.

\section{Conclusions}

Acemoglu and Pischke's seminal model is able to explain training in imperfect labor markets, and it was able to explain why the German system of apprentice training led to a low wage-low mobility-high training equilibrium in the 1990s: Imperfections of the German labor markets, such

\footnotetext{
${ }^{6}$ Representatives of the public are especially school boards and the Federal Research Institute on Vocational Training.
} 
as a medium centralized system of collective bargaining, resulted in a high wage compression during that time.

Since then, however, wage compression has decreased due to changes in the system of collective bargaining and the higher wage inequality connected with this. On the other side, firms' training costs have decreased enormously. Against this background, we contribute to the literature with a continuation of Acemoglu and Pischke's model:

- First, we incorporate wage compression due to collective bargaining. Thus our enhanced model allows for an analysis of the impact of more decentralized wage bargaining on the training equilibrium: Confronted with lower future returns of training, many firms' only option is to either stop apprenticeship training or reduce training costs.

- Second, we analyze how the different components of firms' training costs influence the training equilibrium.

On this basis, it is possible to draw conclusions as to how the training equilibrium is affected by lower direct training costs, lower apprentice wages, and a higher productivity of apprentices.

Furthermore, we present more detailed empirical evidence in order to demonstrate that such an enhancement of Acemoglu and Pischke's model is necessary and useful.

- The last two decades have seen a strong trend towards decentralization of wage bargaining, due to a persistent process of disorganization and more opening clauses in central contracts. As many surveys show, this resulted in higher wage inequality and lower rents from skilled workers.

- Firms' net costs of training slumped from $€ 6,000$ in 2000 to $€ 3,600$ in 2007 . However, the different cost components developed very diversely. Direct training costs rose by 3 percent and apprentice wages by 14 percent - this alone would have led to higher training costs. What was crucial for lower net training costs, however, was that apprentices' productivity rose by nearly 50 percent because many firms fundamentally changed their apprenticeship training: They train much less on internal courses and in firms' training centers and considerably more at the workplace.

- Firms did not reduce their supply of training positions between 2000 and 2007, and the number of apprentices remained unchanged -1.78 million. Thus, still more than 60 percent of an age cohort were able to and did do an apprenticeship.

Finally, it is necessary to carry out further research based on our continuation of Acemoglu and Pischke's model.

- First, we presented empirical evidence that the increase of wage differentials may have caused a decrease in firms' training costs. This hypothesis has to be tested empirically. 
- Second, further research is necessary to find out why firms suddenly train much more at the workplace and how this affects training quality. One reason could be that work organization and production processes have changed, which has led to alterations in skill requirements and training processes. Another reason could be that the regulatory framework of apprentice training changed, which has led to a more flexible training system that allows for more firmspecific approaches and more training at the workplace. 


\section{References}

Acemoglu, D. and Pischke, J. S. (1998), Why do firms train? Theory and evidence. Quarterly Journal of Economics, 113 (1), pp. 79-119.

Acemoglu, D. and Pischke, J. S. (1999), Beyond Becker: Training in imperfect labour markets. Economic Journal, 109 (453), pp. F112-F142.

Bahl, A., Koch, J., Meerten, E., and Zinke, G. (2004), Was bedeutet prozessbezogen ausbilden? Berufsbildung in Wissenschaften und Praxis, 33 (5), pp. 10-14.

Baethge, M. (2001), Qualifikationsentwicklung im Dienstleistungssektor. In: Baethge, M and Wilkens, I (Eds.), Die große Hoffnung für das 21. Jahrhundert? Perspektiven und Strategien für die Entwicklung der Dienstleistungsbeschäftigung. Opladen: Leske + Budrich, pp. 85-106.

Baethge, M., Baethge-Kinsky, V., Holm, R., and Tullius, K. (Eds.) (2006), Dynamische Zeiten langsamer Wandel: Betriebliche Kompetenzentwicklung von Fachkräften in zentralen Tätigkeitsfeldern der deutschen Wirtschaft. Schlussbericht des Forschungsvorhabens: Kompetenzentwicklung in deutschen Unternehmen. Formen, Voraussetzungen und Veränderungsdynamik. Göttingen: SOFI.

Becker G. S. (1964), Human Capital: A Theoretical and Empirical Analysis, with Special Reference to Education. 1st edition, Chicago: The University of Chicago Press.

Beicht U., Walden G., and Herget H. (2004), Kosten und Nutzen der betrieblichen Berufsausbildung in Deutschland. Bielefeld: Bertelsmann-Verlag.

Bispinck, R. (2007), Löhne, Tarifverhandlungen und Tarifsystem in Deutschland 1995-2005. WSI Diskussionspapier 50, Düsseldorf: WSI.

Bispinck, R. and Schulten T. (2003), Verbetrieblichung der Tarifpolitik? Aktuelle Tendenzen und Einschätzungen aus Sicht von Betriebs- und Personalräten. WSI-Mitteilungen, 56 (3), pp. 157-166.

Brändle, T., Heinbach, W. D., and Meier, M.F. (2011), Tarifliche Öffnung in Deuschland: Ausmaß, Determinanten, Auswirkungen. Journal for Labour Market Research, 44 (1-2), pp. 163-172.

Bremer, R. and Hassler, B. (2004), Analyse der Entwicklung fachlicher Kompetenz und beruflicher Identität in der beruflichen Erstausbildung. Zeitschrift für Pädagogik, 50 (2), pp. 162-181.

Bundesministerium für Bildung und Forschung (2009), Berufsbildungsbericht. Berlin: Deutscher Bundestag.

Busemeyer, M. R. (2009), Wandel trotz Reformstau: Die Politik der beruflichen Bildung seit 1970. Frankfurt am Main, New York: Campus.

Busemeyer, M. R., Neubäumer, R., Pfeifer, H., and Wenzelmann, F. (2012), The transformation of the German vocational training regime: Evidence from firms' training behavior. Industrial Relations Journal, 43 (6), pp. 572-591.

Card, D., Heining J., and Kline, P. (2012), Workplace heterogeneity and the rise of German wage inequality. Discussion Paper UC Berkeley and NBER, 2012 (published 2013 in: The Quarterly Journal of Economics, 128 (3), pp. 967-1015). 
Calmfors, L. (1993), Centralisation of wage bargaining and macroeconomic performance: A survey. OECD Economic Studies 21, pp. 161-191.

Calmfors, L. and Driffill, J. (1988), Bargaining structure, corporatism and macroeconomic performance. Economic Policy, 3 (6), pp. 13-61.

DiNardo, J. E., Fortin, N., and Lemieux, T. (1996), Labor market institutions and the distribution of wages, 1973-1992: A semiparametric approach. Econometrica, 64 (5), pp. 1001-1044.

Dustmann, C., Ludsteck, J., and Schönberg, U. (2009), Revisiting the German wage structure. The Quarterly Journal of Economics, 124 (2), pp. 843-881.

Dustman, C., Fitzenberger, B., Schönberg, U., and Spitz-Oener, A. (2012), From sick man of Europe to economic superstar: Germany's resurgent economy. Journal of Economic Perspectives, 28 (1), pp. $167-188$.

Ellguth, P. and Kohaut, S. (2007), Tarifbindung und betriebliche Interessenvertretung: Aktuelle Ergebnisse aus dem IAB-Betriebspanel 2006. WSI-Mitteilungen, 60 (9), pp. 511-514.

Franz, W. (1982), Youth Unemployment in the Federal Republic of Germany: Theory, Empirical Results, and Policy Implications. An Economic Analysis. Tübingen: Mohr.

Franz, W. and Soskice, D. (1995), The German apprenticeship system. In: Buttler, F, Franz, W, Schettkat, R, and Soskice, D (Eds.), Institutional Frameworks and Labour Market Performance. London, New York: Routledge, pp. 208-234.

Freeman, R. B. and Schettkat, R. (2001), Skill compression, wage differentials, and employment: Germany vs. the US. Oxford Economic Papers, 53 (3), pp. 582-603.

Garloff, A. and Guertzgen, N. (2012), Collective wage contracts, opt-out clauses, and firm wage differentials. Industrial Relations, 51 (3), pp. 731-748.

Gerlach, K. and Stefan, G. (2006), Bargaining regimes and wage dispersion. Jahrbücher für Nationalökonomie und Statistik, 226 (6), pp. 629-645.

Gernandt, J. and Pfeiffer, F. (2006), Rising wage inequality in Germany. ZEW Discussion Paper 06-1, Mannheim: ZEW.

Grollmann, P. and Rauner, F. (2007), Exploring innovative apprenticeship: Quality and costs. Education + Training, 49 (6), pp. 431-446.

Jürgens, U. (2006), Weltweite Trends in der Arbeitsorganisation. In: Clement, U and Lacher, M (Eds.), Produktionssysteme und Kompetenzerwerb: Zu den Veränderungen moderner Arbeitsorganisation und ihren Auswirkungen auf die berufliche Bildung. Stuttgart: Franz Steiner Verlag, pp. 15-29.

Katz, E. and Ziderman, A. (1990), Investment in general training: The role of information and labour mobility. The Economic Journal, 100 (403), pp. 1147-1158.

Koch, J. and Meerten, E. (2003), Prozessorientierte Qualifizierung - Paradigmawechsel in der beruflichen Bildung. Berufsbildung in Wissenschaften und Praxis, 32 (5), pp. 42-46.

Kohn, K. (2006), Rising wage dispersion, after all! The German wage structure at the turn of the century. IZA Discussion Paper 2098, Bonn: IZA. 
Lacher, M. (2006), Ganzheitliche Produktionssysteme, Kompetenzerwerb und berufliche Bildung. In: Clement, $\mathrm{U}$ and Lacher, $\mathrm{M}$ (Eds.), Produktionssysteme und Kompetenzerwerb: zu den Veränderungen moderner Arbeitsorganisation und ihren Auswirkungen auf die berufliche Bildung. Stuttgart: Franz Steiner Verlag, pp. 73-91.

Leuven E. (2005), The economics of private sector training: a survey of the literature. Journal of Economic Surveys, 19 (1), pp. 91-111.

Neubäumer, R. (1993), Betriebliche Ausbildung 'über Bedarf' - Empirische Ergebnisse und ein humankapitaltheoretischer Ansatz. Jahrbuch für Sozialwissenschaft, 44 (1), pp. 104-131.

Neubäumer R. (1999), Der Ausbildungsstellenmarkt der Bundesrepublik Deutschland. Eine theoretische und empirische Analyse. Berlin: Duncker \& Humblot.

Oechel, W. (2005), Decentralizing and wage bargaining in Germany - A way to increased employment. Labour, 19 (1), pp. 91-121.

Rowthorn, R. E. (1992), Centralisation, employment and wage dispersion. The Economic Journal, 102 (412), pp. 506-523.

Ryan, P. (2001), The school-to-work-transition: a cross-national perspective. Journal of Economic Literature, 39 (1), pp. 34-92.

Sachverständigenkommission Kosten und Finanzierung der beruflichen Bildung (1974), Kosten und Finanzierung der außerschulischen beruflichen Bildung. Bielefeld: Bertelsmann-Verlag.

Sauter, E. (1999), Risiken und Chancen des Lernens im Arbeitsprozess. Berufsbildung: europäische Zeitschrift, 17 (1), pp. 15-25.

Schettkat, R. (2003), Koordination von Lohnverhandlungen. Mitteilungen aus der Arbeitsmarkt- und Berufsforschung, 36 (4), pp. 634-648.

Schnabel, C. and Wagner, J. (2006), The persistent decline in unionization in Western and Eastern Germany, 1980-2004: What can we learn from a decomposition analysis? IZA Discussion Paper 2388, Bonn: IZA.

Schönfeld, G., Wenzelmann, F., Dionisius, R., Pfeifer, H., and Walden, G. (2010), Kosten und Nutzen der dualen Ausbildung aus Sicht der Betriebe. Ergebnisse der vierten BIBB-Kosten-Nutzen-Erhebung. Bielefeld: Bertelsmann-Verlag.

Seifert, H. and Massa-Wirth, H. (2005), Pacts for employment and competitiveness in Germany. Industrial Relations Journal, 36 (3), pp. 217-240.

Severing, E. (2003), Lernen im Arbeitsprozess: Eine pädagogische Herausforderung. Grundlagen der Weiterbildung, 14 (1), pp. 1-4.

Silvia, S. J. and Schröder, W. (2007), Why are German employers' associations declining? Arguments and evidence. Comparative Political Studies, 40 (12), pp. 1433-1459.

Springer, R. (1999), The end of new production concepts? Rationalization and labour policy in the German auto industry. Economic and Industrial Democracy, 20 (1), pp. 117-145. 
Graph 1: Profits from Training as a Function of the Rent through Wage Compression due to Collective Bargaining (Simulation)

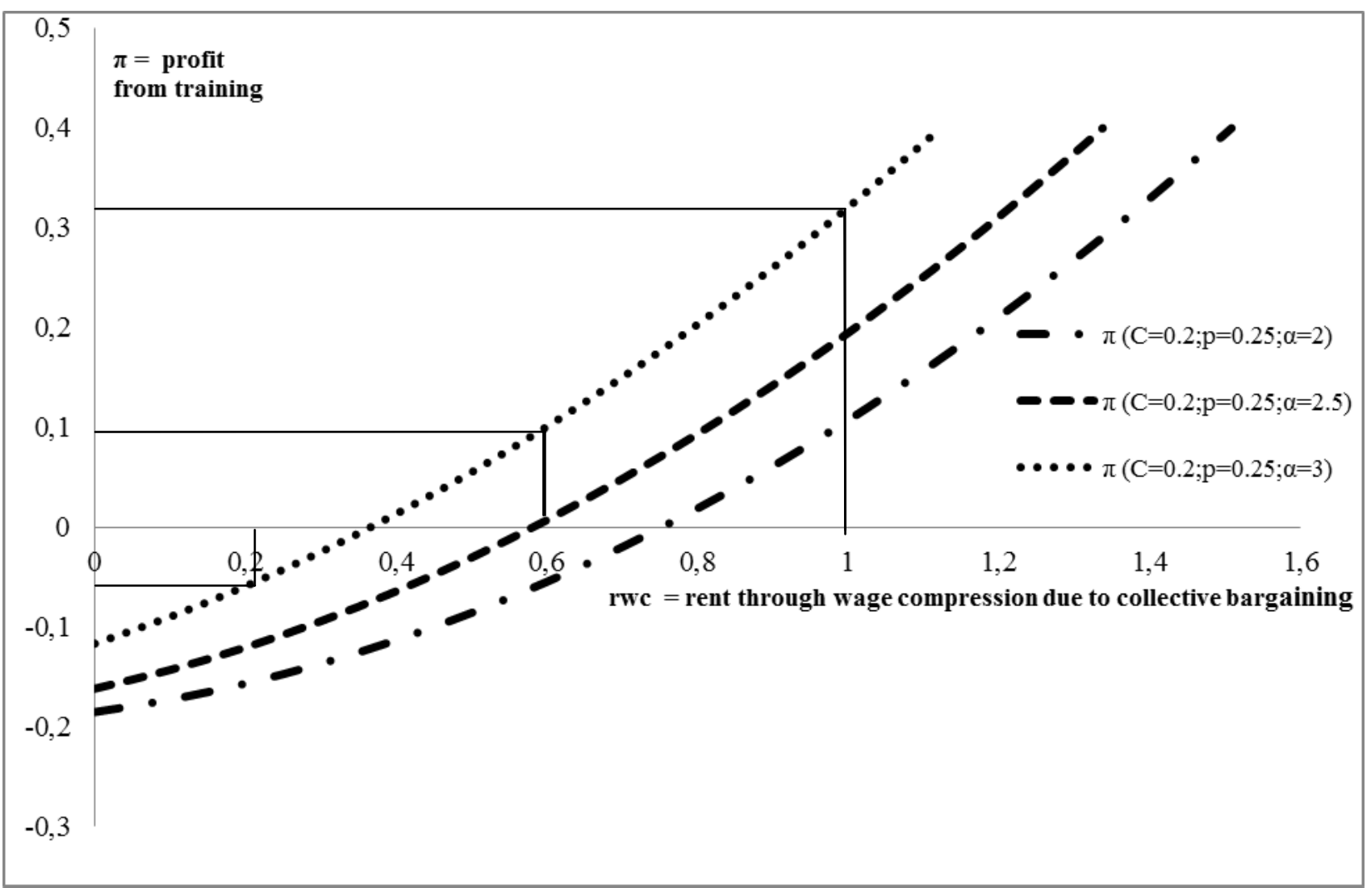

Note: The profit from training $(\pi)$ also depends on firms' training costs $(C=0.2)$, the share of highability apprentices $(1-p=1-0.25)$, and three productivity levels of graduated apprentices $\left(\alpha_{1}=2\right.$; $\alpha_{2}=2.5 ; \alpha_{3}=3$ ).

Source: Own simulation. 
Table 1: Wage Dispersion, 1992 and 2001 in Germany

\begin{tabular}{|c|c|c|c|}
\hline $\begin{array}{l}\text { Percentile } \\
\text { differences }\end{array}$ & 1992 & 2001 & $\begin{array}{l}\text { Change between } \\
1992 \text { and } 2001\end{array}$ \\
\hline & \multicolumn{3}{|c|}{ Men, West } \\
\hline PD80-20 & 0.538 & 0.628 & 0.090 \\
\hline PD50-20 & 0.226 & 0.259 & 0.033 \\
\hline \multirow[t]{2}{*}{ PD80-50 } & 0.312 & 0.369 & 0.057 \\
\hline & \multicolumn{3}{|c|}{ Men, East } \\
\hline PD80-20 & $*$ & 0.639 & \\
\hline PD50-20 & 0.220 & 0.277 & 0.057 \\
\hline \multirow[t]{2}{*}{ PD80-50 } & $*$ & 0.362 & \\
\hline & \multicolumn{3}{|c|}{ Women, West } \\
\hline PD80-20 & 0.649 & 0.723 & 0.074 \\
\hline PD50-20 & 0.368 & 0.412 & 0.044 \\
\hline \multirow[t]{2}{*}{ PD80-50 } & 0.281 & 0.311 & 0.030 \\
\hline & \multicolumn{3}{|c|}{ Women, East } \\
\hline PD80-20 & 0.567 & 0.867 & 0.300 \\
\hline PD50-20 & 0.317 & 0.490 & 0.173 \\
\hline PD80-50 & 0.250 & 0.377 & 0.127 \\
\hline \multicolumn{4}{|c|}{$\begin{array}{l}\text { Notes: }{ }^{1} \text { PD } 80-20 \text { is the difference between the } 80^{\text {th }} \text { percentile and the } 20^{\text {th }} \\
\text { percentile etc. } \\
\text { * indicates censored percentiles. } \\
\text { Source: IABS } 1992-2001 \text { (Kohn, 2006). }\end{array}$} \\
\hline
\end{tabular}


Table 2: German Firms' Costs and Benefits of Apprenticeship Training, 2000 and 2007

\begin{tabular}{|l|l|l|l|}
\hline & 2000 & 2007 & $\begin{array}{l}\text { Growth rates } \\
\text { between } 2000 \text { and } 2007\end{array}$ \\
\hline & $€^{1}$ & $€^{1}$ & percentage changes \\
\hline firms' gross costs of training $\left(\mathrm{C}_{\mathrm{g}}\right)$ & 13,933 & 15,288 & +9.7 \\
\hline $\begin{array}{l}\text { of which } \\
- \text { apprentice wages }\left(\mathrm{w}_{\mathrm{a}}\right)\end{array}$ & 8,321 & 9,490 & +14.1 \\
\hline- direct training costs $\left(\mathrm{c}_{\mathrm{d}}\right)^{2}$ & 3,880 & 3,983 & +2.7 \\
\hline firms' benefits of training $\left(\alpha_{\mathrm{a}}\right)^{3}$ & 7,900 & 11,692 & +48.0 \\
\hline $\begin{array}{l}\text { firms' net costs of training } \\
\left(\mathrm{C}=\mathrm{c}_{\mathrm{d}}+\mathrm{w}_{\mathrm{a}}-\alpha_{\mathrm{a}}\right)\end{array}$ & 6,033 & 3,596 & -40.4 \\
\hline
\end{tabular}

Notes: 1 On average per apprentice and year. 2 Costs of training personnel and firms' expenses for material, infrastructure, etc. 3 Productivity of apprentices.

Source: Cost-Benefit-Survey 2000 and 2007 of the Bundesinstitut für Berufsbildung (BIBB) (Federal Institute of Vocational Education and Training) (Beicht et al., 2004; Schönfeld et al., 2010). 
Table 3: Development of Apprenticeship Positions, 2000 and 2007 in Germany

\begin{tabular}{|c|c|c|c|}
\hline & 2000 & 2007 & $\begin{array}{l}\text { Growth rates } \\
\text { (percentage } \\
\text { changes) }\end{array}$ \\
\hline School-leavers (thousands) ${ }^{1}$ & 919 & 942 & +3.0 \\
\hline Demand for apprentice positions (thousands) ${ }^{2}$ & 645 & 659 & +2.0 \\
\hline Supply of apprentice positions (thousands) ${ }^{2}$ & 647 & 644 & -0.5 \\
\hline Apprentices (thousands) $)^{2}$ & 1,779 & 1,781 & +0.1 \\
\hline Employees (thousands) $^{3}$ & 35,229 & 35,288 & +0.2 \\
\hline \multicolumn{4}{|c|}{$\begin{array}{l}\text { Sources: } 1 \text { Berufsbildungsbericht des Bundesministeriums für Bildung und Forschung (2009 } \\
\text { (Report on Vocational Training of the Federal Ministry of Education and Research) } \\
2 \text { Bundesinstitut für Berufsbildung (BIBB) (Federal Institute for Vocational Education an } \\
\text { Training). } 3 \text { Deutsche Bundesbank (German Central Bank). }\end{array}$} \\
\hline
\end{tabular}

